\title{
How important are mangroves and seagrass beds for coral-reef fish? The nursery hypothesis tested on an island scale
}

\author{
I. Nagelkerken ${ }^{1,3, *}$, C. M. Roberts ${ }^{4}$, G. van der Velde ${ }^{1}$, M. Dorenbosch ${ }^{1}$, M. C. van $\operatorname{Riel}^{1}$, \\ E. Cocheret de la Morinière ${ }^{1}$, P. H. Nienhuis ${ }^{2}$ \\ ${ }^{1}$ Department of Animal Ecology and Ecophysiology, Aquatic Animal Ecology Section, and ${ }^{2}$ Department of Environmental Studies, \\ University of Nijmegen, Toernooiveld 1, 6525 ED Nijmegen, The Netherlands \\ ${ }^{3}$ Carmabi Foundation, PO Box 2090, Piscaderabaai z/n, Curaçao, Netherlands Antilles \\ ${ }^{4}$ Environment Department, University of York, York YO10 5DD, United Kingdom
}

\begin{abstract}
There has been much controversy over the degree to which mangroves and seagrass beds function as nursery habitats for the juveniles of fish species that live on coral reefs as adults. In previous studies we have shown that the juveniles of at least 17 Caribbean reef-fish species are highly associated with bays containing mangroves and seagrass beds as nurseries, and that juveniles of these species are absent in bays lacking such habitats. In this study we therefore hypothesised that on islands lacking these bay nursery habitats, adults of these fish species will be absent or show low densities on the coral reef. Densities of the 17 species were compared between the reefs of Caribbean islands with and without mangroves and seagrass beds. On reefs of islands lacking these habitats, complete absence or low densities were observed for 11 of the 17 species, several of which are of commercial importance to fisheries. This finding suggests a very important nursery function of such habitats and implies that the densities of several fish species on coral reefs are a function of the presence of nearby bays containing mangroves and seagrass beds as nurseries. The results indicate that degradation or loss of these habitats could have significant impacts on reef-fish stocks in the Caribbean.
\end{abstract}

KEY WORDS: Habitat dependence - Coral-reef fish . Mangroves $\cdot$ Seagrass beds $\cdot$ Nursery

Resale or republication not permitted without written consent of the publisher

Coastal ecosystems are in world-wide decline as a result of anthropogenic disturbances. Estimates suggest that 30 to $60 \%$ of the world's mangroves have already been lost and seagrasses are declining at similar rates (Shepherd et al. 1989, Spalding 1998). Many studies have shown that mangroves and seagrass beds

*Email: i.nagelkerken@sci.kun.nl harbour high densities of juvenile reef fish (see reviews by Parrish 1989, Robertson \& Blaber 1992), but few have investigated juvenile densities on the coral reef to determine the relative nursery importance of each of these habitats. Hence, the extent to which fishery yields from coral reefs are a function of the presence of mangroves and/or seagrass nursery habitats remains unclear (Parrish 1989, Roberts 1996). If nursery habitats support fishery production from reefs, they must also be managed in order to sustain yields, since reef fisheries are critical to millions of people world-wide (Munro 1996).

In the Caribbean, we found that mangroves and seagrass beds function as nurseries for the juveniles of at least 17 different reef fish species (defined as 'nursery species'), many of them commercially important to the reef fisheries (Nagelkerken et al. 2000a,b, 2001, Nagelkerken \& van der Velde 2002, in press). Lagoons and bays containing mangroves and seagrass beds are ideal nurseries for the juveniles of these species because of the high abundance of food and shelter, and a reduced predation pressure (Blaber \& Blaber 1980, Shulman 1985, Parrish 1989, Laegdsgaard \& Johnson 2001). At a certain life-stage, these fish migrate permanently from their nursery habitats to the adjacent coral reef (Nagelkerken et al. 2000a,b, Nagelkerken \& van der Velde 2002, in press, Cocheret de la Morinière et al. 2002).

Aside from the high abundance of juvenile fish in mangroves and seagrass beds, the above studies also suggested a high dependence on these habitats. A comparison between bays of a single island with and without mangroves and/or seagrass beds showed that 
juveniles of the 17 species were highly abundant in mangrove and seagrass dominated bays, but were largely absent in bays lacking these nursery habitats (Nagelkerken et al. 2001). Furthermore, the juveniles of these reef-fish species almost exclusively occur in bays with mangroves and seagrass beds and are seldom found on the coral reef, as shown by monitoring of juvenile fish densities at the reefs of the Caribbean islands of Curaçao and Bonaire (Nagelkerken et al. 2000a,b, Nagelkerken \& van der Velde 2002, in press).

If these species show a dependence on mangroves and seagrass beds as nurseries, and alternative nurseries are not available or suitable, their adult densities on the coral reef should be a function of the presence of mangroves and seagrass beds. This hypothesis was tested for the 17 reef-fish species. We compared adult fish densities on reefs at 3 Caribbean islands with and without mangroves and seagrass beds. It was expected that densities of adults of these species on the coral reefs of islands lacking these nursery habitats would be low to zero.

Materials and methods. Fish counts of the 17 Caribbean reef-fish species which use mangroves and seagrass beds as nurseries during their juvenile stage (following Nagelkerken et al. 2000a, see Table 1) were made on the reefs of islands with and without bays containing mangroves and seagrass beds. The islands with bays containing these nursery habitats were Bonaire, Curaçao and Puerto Rico; the islands lacking bays (and thus also these bay nursery habitats) were Saba, Klein Bonaire and Klein Curaçao (Netherlands Antilles) (Fig. 1).

The reefs of Bonaire, Curaçao, Klein Bonaire and Klein Curaçao generally consist of a narrow submarine terrace ( $<250 \mathrm{~m}$ wide) which gradually slopes from the shore to a 'drop-off' at approximately 7 to $12 \mathrm{~m}$ depth. At the drop-off, the reef slopes off steeply, sometimes interrupted by a small second terrace at 50 to $60 \mathrm{~m}$, and ends in a sandy plain at 80 to $90 \mathrm{~m}$ (Bak 1975). The drop-off zone shows maximum diversity of benthos and maximum coral cover. For a detailed description of the reef structure and distribution of corals on the reefs of the Netherlands Antilles, see Bak (1975). Saba also has a relatively narrow shelf which is a remnant of the volcano which forms the island. Reef development is poor compared to Bonaire, Curaçao, Klein Bonaire and Klein Curaçao, and reefs are largely encrusted onto the volcanic boulder substrata. For a more detailed description of the reef structure of Saba, see Buchan (1998). At La Parguera, Puerto Rico, the studied reefs are patch reefs surrounding islets which are situated on the relatively wide shelf (up to $10 \mathrm{~km}$ ). For a more detailed description of the reef structure of Puerto Rico, see García et al. (1998).

Fish counts were made during daytime at all 6 islands at 5 and $15 \mathrm{~m}$ depth at various reef sites (Fig. 1), using a stationary point-count method (Polunin \& Roberts 1993). Surveys in Curaçao were carried out between 6 December 1999 and 12 January 2000 at 4 reef sites near to bays containing mangroves and seagrass beds. At each site, 8 counts were done at each

Table 1. Mean density (ind. per $1000 \mathrm{~m}^{2}$ ) and maximum size of juveniles of the 17 nursery species in mangroves, seagrass beds and coral reefs on Curaçao and Bonaire. $\mathrm{nd}=$ no data; $\mathrm{N}=$ no. of transects sampled $\left(150 \mathrm{~m}^{2}\right.$ each)

\begin{tabular}{|c|c|c|c|c|c|c|c|}
\hline \multirow[t]{2}{*}{ Species (common name) } & \multirow{2}{*}{$\begin{array}{l}\text { Max. size } \\
\quad(\mathrm{cm})\end{array}$} & \multicolumn{3}{|c|}{$\longrightarrow$ Curaçao $\longrightarrow$} & \multicolumn{3}{|c|}{ Bonaire- } \\
\hline & & Mangrove & $\begin{array}{c}\text { Seagrass } \\
\text { bed }\end{array}$ & $\begin{array}{l}\text { Coral } \\
\text { reef }\end{array}$ & Mangrove & $\begin{array}{c}\text { Seagrass } \\
\text { bed }\end{array}$ & $\begin{array}{c}\text { Coral } \\
\text { reef }\end{array}$ \\
\hline Acanthurus chirurgus (doctorfish) & 17.5 & 10.7 & 7.5 & 1.2 & 8.0 & 92.0 & 14.1 \\
\hline Chaetodon capistratus (foureye butterflyfish) & 7.5 & 88.3 & 10.0 & 6.6 & 86.0 & 36.0 & 1.0 \\
\hline Gerres cinereus (yellowfin mojarra) & 15.0 & 171.6 & 2.0 & 0.1 & nd & nd & nd \\
\hline Haemulon flavolineatum (French grunt) & 12.5 & 791.3 & 176.4 & 5.2 & 581.0 & 1153.0 & 181.8 \\
\hline Haemulon parra (sailors choice) & 20.0 & 60.6 & 0.3 & 0.0 & nd & nd & nd \\
\hline Haemulon plumieri (white grunt) & 15.0 & 2.1 & 1.2 & 0.0 & nd & nd & nd \\
\hline Haemulon sciurus (bluestriped grunt) & 15.0 & 205.3 & 23.6 & 0.2 & 16.1 & 50.0 & 0.4 \\
\hline Lutjanus analis (mutton snapper) & 37.5 & 2.8 & 3.3 & 0.1 & nd & nd & nd \\
\hline Lutjanus apodus (schoolmaster) & 20.0 & 272.5 & 1.5 & 1.1 & 477.0 & 81.0 & 2.5 \\
\hline Lutjanus griseus (gray snapper) & 17.5 & 44.3 & 4.1 & 0.1 & 194.0 & 80.4 & 0.0 \\
\hline Lutjanus mahogoni (mahogany snapper) & 20.0 & 11.8 & 0.5 & 1.2 & 0.0 & 10.4 & 34.9 \\
\hline Ocyurus chrysurus (yellowtail snapper) & 22.5 & 45.5 & 19.2 & 4.0 & 12.0 & 164.0 & 21.6 \\
\hline Scarus coeruleus (blue parrotfish) & 30.0 & 0.0 & 3.9 & 0.7 & nd & nd & nd \\
\hline Scarus guacamaia (rainbow parrotfish) & nd & nd & nd & nd & nd & nd & nd \\
\hline Scarus iserti (striped parrotfish) & 15.0 & 73.3 & 151.8 & 35.2 & nd & nd & nd \\
\hline Sparisoma chrysopterum (redtail parrotfish) & 20.0 & 13.0 & 3.3 & 2.5 & nd & nd & nd \\
\hline Sphyraena barracuda (great barracuda) & 45.0 & 13.7 & 0.8 & 0.0 & 46.0 & 7.1 & 0.1 \\
\hline $\mathbf{N}$ & & 85 & 87 & 108 & 196 & 84 & 372 \\
\hline
\end{tabular}




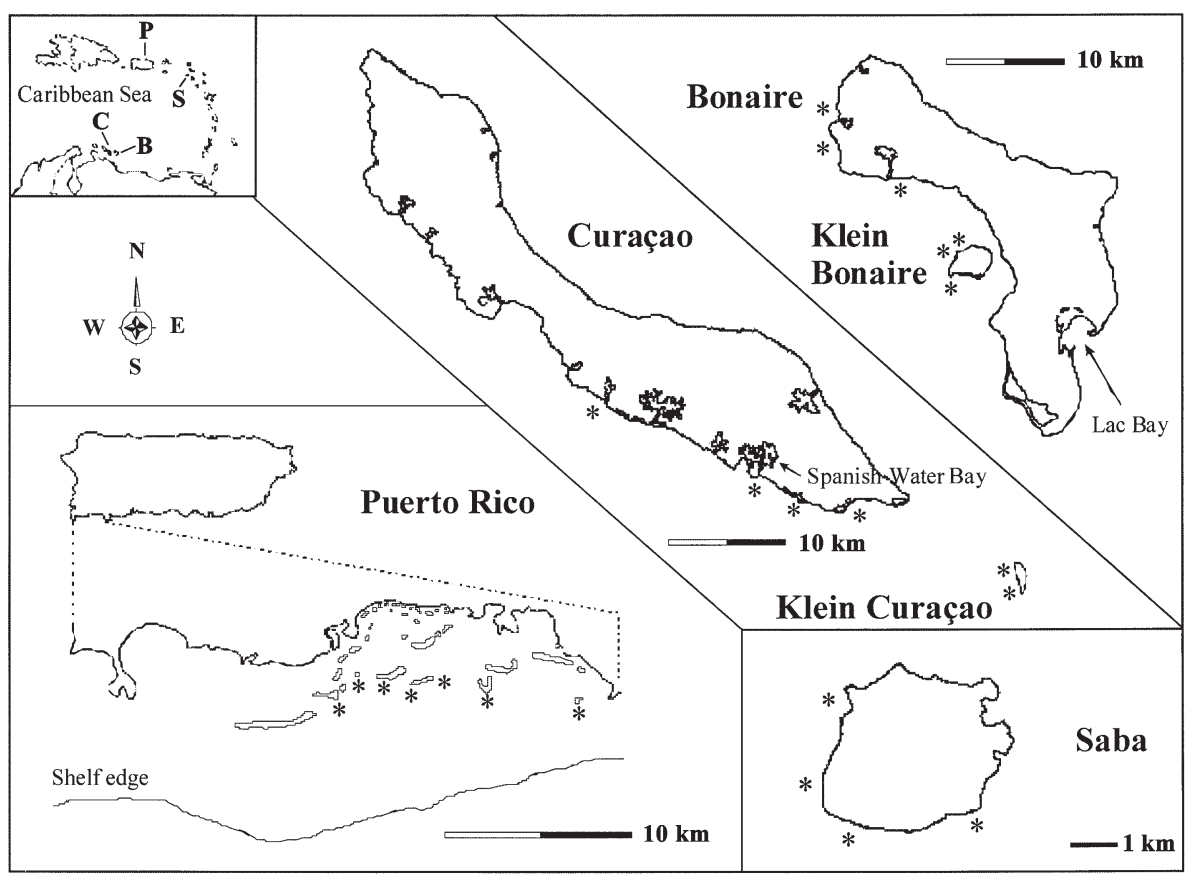

Fig. 1. Location of the islands and study sites (*). The inset Caribbean Sea shows: B, Bonaire and Klein Bonaire; C, Curaçao and Klein Curaçao; P, Puerto Rico; S, Saba

depth. In Klein Curaçao, 4 to 6 counts per depth were done at 2 sites on 7 November 1999; the surveys were repeated in the same reef areas but not at the exact same sites on 14 November 1999 and 6 February 2000. In Bonaire and Klein Bonaire, 6 counts were done at each depth at 3 sites during 1994. In Saba, 5 to 32 counts were done at each depth at 4 sites during 1996. In Puerto Rico, 6 to 8 counts were done at each depth at 7 sites during 1995.

Fish densities (5 and $15 \mathrm{~m}$ counts pooled) were statistically compared between sets of islands which were located close to one another: Curaçao vs Klein Curaçao, Bonaire vs Klein Bonaire, and Puerto Rico vs Saba. The comparisons were done using a MannWhitney $U$-test and in a few cases, where the data were normally distributed, a nested ANOVA was used on log-transformed data, with Transects nested under Site.

To confirm the high association of juveniles of the 17 fish species with mangroves and seagrass beds, daytime fish densities of juveniles (i.e. all fishes smaller than the minimum maturation size, as derived from R. Froese \& D. Pauly [eds] 2002, FishBase; available at www.fishbase.org) were determined in the mangroves, seagrass beds and coral reefs of Curaçao and Bonaire, using a visual census technique in belt transects. All transects were surveyed with the same technique and surveys were done during the same sampling period for reef and bay habitats of each island. Mangroves and seagrass beds were only present in Lac Bay on Bonaire, whereas in Curaçao the bay with the largest mangrove and seagrass area on the sheltered south-western coast of the island (i.e. Spanish Water Bay) was selected (Fig. 1). On the reef, different sites were surveyed for the comparison of fish densities between the 3 sets of islands. For a detailed description of the sampling methodology, study design and research sites see Nagelkerken et al. 2000a (Curaçao) and Nagelkerken et al. 2000b (Bonaire).

Results and discussion. Juveniles of the 17 fish species were in all cases (except Lutjanus mahogoni in Bonaire) highly associated with mangroves and/or seagrass beds, but showed much lower densities or complete absence on the coral reef (Table 1). High densities of juveniles were also found in all other mangrove and seagrass dominated bays of Curaçao (Nagelkerken et al. 2001). These data thus show that mangroves and seagrass beds, and not coral reefs, are of high importance as nursery habitats for juveniles of the 17 nursery species. The circumtropical species Sphyraena barracuda shows a similar habitat utilisation in the Indo-West Pacific, where juveniles are found in mangroves and reed beds, and adults on coral reefs (Blaber 1997).

The 17 nursery species could be divided into 3 groups, based on comparison of the adult reef-fish 
Table 2. Mean densities of adult nursery species (ind. per $1000 \mathrm{~m}^{2}$ ) on coral reefs of islands with and without mangroves and seagrass beds. $+=$ present, $-=$ absent, nd = no data. ${ }^{*}$ Significant difference (Mann-Whitney $U$-test or nested ANOVA, p $<0.05$ ); some large differences were not significant because of several zero-values in some transects. Haemulon parra was not observed within any of the reef transects

\begin{tabular}{|c|c|c|c|c|c|c|c|}
\hline & Curaçao & $\begin{array}{l}\text { vs Klein } \\
\text { Curaçao }\end{array}$ & Bonaire vs & $\begin{array}{l}\text { Klein } \\
\text { Bonaire }\end{array}$ & $\begin{array}{l}\text { Puerto } \\
\text { Rico }\end{array}$ & vs & Saba \\
\hline Presence of mangroves and seagrass beds & + & - & + & - & + & & - \\
\hline No. of transects sampled ( $78.5 \mathrm{~m}^{2}$ each) & 64 & 60 & 36 & 36 & 98 & & 67 \\
\hline Density of total fish community & nd & nd & 5808 & 5000 & 1190 & & $3223^{*}$ \\
\hline \multicolumn{8}{|c|}{ Species with high dependence on mangrove and/or seagrass nurseries } \\
\hline Haemulon sciurus (bluestriped grunt) & 7.0 & $0.0^{*}$ & 3.9 & $0.7^{*}$ & 0.6 & & 0.0 \\
\hline Lutjanus apodus (schoolmaster) & 44.8 & $17.9^{*}$ & 22.6 & $7.8^{*}$ & 8.1 & & 3.5 \\
\hline Ocyurus chrysurus (yellowtail snapper) & 62.1 & $2.8^{*}$ & 46.7 & $15.2^{*}$ & 4.8 & & $0.0^{*}$ \\
\hline Scarus iserti (striped parrotfish) & 84.8 & $0.9^{*}$ & 68.3 & $9.9^{*}$ & 152.1 & & $0.0^{*}$ \\
\hline \multicolumn{8}{|c|}{ Species with possible dependence on mangrove and/or seagrass nurseries } \\
\hline Gerres cinereus (yellowfin mojarra) & 0.4 & 0.0 & 0.7 & 0.0 & 0.0 & & 1.2 \\
\hline Haemulon plumieri (white grunt) & 0.0 & 0.0 & 0.0 & 0.0 & 4.3 & & $0.0^{*}$ \\
\hline Lutjanus analis (mutton snapper) & 2.2 & $0.0^{*}$ & 0.0 & 0.0 & 0.1 & & 0.0 \\
\hline Lutjanus griseus (gray snapper) & 1.6 & $0.0^{*}$ & 0.0 & 0.0 & 0.0 & & 0.0 \\
\hline Scarus coeruleus (blue parrotfish) & 4.8 & $0.0^{*}$ & 0.0 & 0.4 & 0.0 & & 0.0 \\
\hline Scarus guacamaia (rainbow parrotfish) & 3.6 & 0.6 & 0.0 & 0.0 & 0.1 & & 0.0 \\
\hline Sphyraena barracuda (great barracuda) & 5.2 & $0.0^{*}$ & nd & nd & nd & & nd \\
\hline \multicolumn{8}{|c|}{ Species without dependence on mangrove and/or seagrass nurseries } \\
\hline Acanthurus chirurgus (doctorfish) & 11.3 & 9.8 & 0.7 & 1.8 & 9.5 & & 7.8 \\
\hline Chaetodon capistratus (foureye butterflyfish) & 25.1 & $28.9^{*}$ & 24.4 & 27.2 & 21.2 & & 21.2 \\
\hline Haemulon flavolineatum (French grunt) & 69.4 & 65.2 & 7.8 & 11.0 & 22.2 & & 8.9 \\
\hline Lutjanus mahogoni (mahogany snapper) & 26.7 & 20.1 & 2.8 & 2.8 & 1.7 & & $12.6^{*}$ \\
\hline Sparisoma chrysopterum (redtail parrotfish) & 4.2 & 3.9 & 0.7 & 0.4 & 0.8 & & 2.1 \\
\hline
\end{tabular}

density between islands with and without mangroves and/or seagrass beds (Table 2). The first group contained the species Haemulon sciurus, Lutjanus apodus, Ocyurus chrysurus and Scarus iserti. The adults of these species on the reef showed significantly lower densities in the absence of mangrove and seagrass nursery habitats for 2 to 3 different sets of islands. For these species, the data suggest a high dependence on the presence of these bay nursery habitats. The second group contained 7 nursery species for which the above pattern was less clear (Table 2). These species were not observed on some of the islands which harboured bay nursery habitats; differences in density between islands with and without mangroves and seagrass beds were only significant for one set of islands, or such differences were present for different sets of islands but not significant. For these species, a possible dependence on the presence of mangroves and seagrass beds is suggested; there may be a real dependence but the evidence is not sufficient to support this.

The observed pattern of lower densities of adults on the reefs of islands without vegetated bays is most likely explained by the absence of suitable bay nursery habitats. It could also be argued that the observed differences between sets of islands are caused by differences in reef morphology and environmental variables. Although this cannot be completely ruled out, the observed difference in density was consistent for several species for more than one comparison between sets of islands. Furthermore, total fish densities on Bonaire and Klein Bonaire were similar (Table 2), indicating that these reefs have an equal capacity of harbouring fish and that differences in environmental factors probably play a minor role. In Saba (without bay nursery habitats), total fish densities were 3 times higher than in Puerto Rico (with bay nursery habitats); nevertheless, adult densities of nursery species depending on mangroves and/or seagrass beds were always higher (except Gerres cinereus) in Puerto Rico than in Saba (Table 2).

The effect of the absence of mangroves and seagrass nursery habitats on an island level was also clearly visible when densities of nursery species showing a high mangrove and/or seagrass dependence and their congeneric species from the reef were pooled at family level and compared between sets of islands (Fig. 2). Pooled densities of nursery species belonging to the families Haemulidae, Lutjanidae and Scaridae were significantly higher at islands with bay nursery habitats than at islands without bay nursery habitats, viz. higher at Bonaire than at Klein Bonaire, and higher at Puerto Rico than at Saba. Pooled densities of congeneric species (i.e. fish species belonging to the same genera as the nursery species, but which do not de- 
pend on mangroves and/or seagrass beds as nurseries) did not show a significant reduction with absence of bay nursery habitats (Fig. 2).

The very low densities of 11 species, of which 4 species showed a highly consistent pattern for the different sets of islands, on reefs of islands without bay nursery habitats supports the hypothesis that mangroves and seagrass beds are important nurseries for juvenile reef fish, and suggests that for several of the nursery species the dependence on these habitats is very high. Hence, the present data imply that, at least for a number of nursery species, densities on the coral reef are a function of the presence of nearby bays containing mangroves and seagrass beds. This is further supported by a study on the Caribbean island of Sombrero (Ogden et al. 1985), which lacks bays with mangroves and seagrass beds and showed complete absence of these 11 species (except Sphyraena barracuda). Miller \& Gerstner (2002) also noted that members of the Haemulidae family were completely absent from the island of Navassa, which also lacks bays with mangroves and seagrass beds. Additionally, Nagelkerken et al. (2000a) found that densities of Lutjanus apodus and Ocyurus chrysurus on the reef of Curaçao decreased with increasing distance from the mouth of Spanish Water Bay, which is a bay harbouring high densities of their juveniles. Furthermore, juvenile nursery species are almost completely absent from bays without mangroves and seagrass beds (Nagelkerken et al. 2001). One exception was Gerres cinereus, of which the juveniles were highly abundant in bays lacking mangroves and seagrass beds (Nagelkerken et al. 2001). Taking the lowered reef densities of this species on Klein Bonaire and Klein Curaçao (both without bays) into consideration, the data suggest that $G$. cinereus depends on the presence of shallow coastal areas such as inland bays as nurseries, and not on mangroves and seagrass beds per se (Nagelkerken et al. 2001). The situation is comparable for 2 species of Gerres in the Pacific, where adults are only found in offshore waters and juveniles only in shallow areas, such as mangroves and seagrass beds, but also on sandy mud beaches in bays and estuaries (Blaber \& Blaber 1980, Blaber et al. 1989).

Five nursery species, Acanthurus chirurgus, Chaetodon capistratus, Haemulon flavolineatum, Lutjanus mahogoni and Sparisoma chrysopterum, did not show lower densities on reefs of islands without bay nursery habitats, even though densities of their juveniles were much higher in mangroves and seagrass beds than on the coral reef (Tables $1 \& 2$ ). This suggests that as juveniles, these species show a 'preference' for (but not a dependence on) mangroves and seagrass beds as nurseries, but can also utilise alternative nurseries when these habitats are absent. It has been shown that $A$.

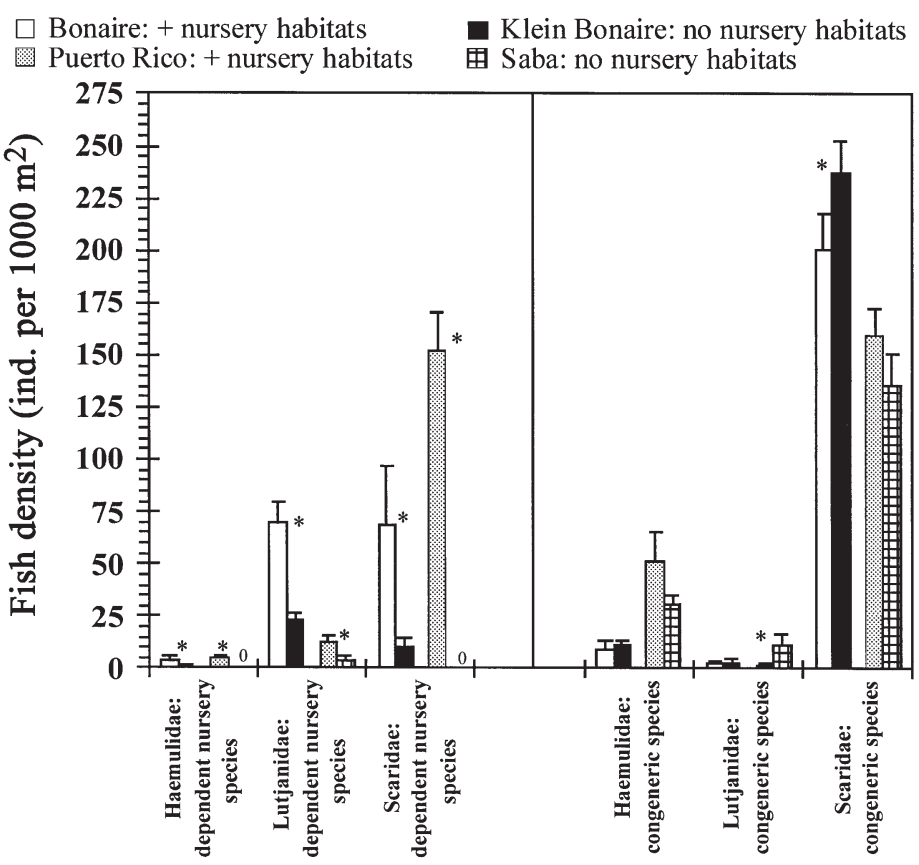

Fig. 2. Mean fish densities $( \pm \mathrm{SE})$ of dependent nursery species (lefthand panel) and their congeneric species (right-hand panel) at the different sets of islands. Dependent nursery species were the 11 species showing dependence on bay nursery habitats; see first 2 groups of Table 2. Congeneric species: sum of non-dependent nursery species from Table 2 plus all other species within the same family; the latter were counted but are not shown in Table 2. * Significant difference between sets of islands (i.e. Bonaire vs Klein Bonaire and Puerto Rico vs Saba). 0: no fish observed. No comparison is made between Curaçao and Klein Curaçao, because densities of congeneric species were not determined at the latter island

chirurgus, H. flavolineatum and L. mahogoni can use the shallow coral reef $(<3 \mathrm{~m}$ depth) as an alternative nursery habitat (Nagelkerken et al. 2000b). For $H$. flavolineatum, Shulman \& Ogden (1987) observed that $95 \%$ of recruits settled in a seagrass-dominated lagoon and only $5 \%$ directly on the reef, yet they calculated that this $5 \%$ was enough to sustain the reef population. Our data confirm that recruitment of this species on the coral reef alone is sufficient to sustain the reef population.

In the Indo-West Pacific, where much research has been done but where the situation is much different from that on Caribbean islands, the dependence on estuaries, as opposed to marine bay habitats, has been tested in various studies. Most estuaries show relatively high fluctuations in turbidity, flow rate, salinity and tidal range, and often lack significant seagrass areas. Notwithstanding the more extreme environment in most estuaries, juveniles of at least 14 species are found only in estuarine waters in north Australia, suggesting a true estuarine-dependence (Blaber et al. 1989); adults of 11 of these species are found only in 
offshore waters. Comparable to the Caribbean, fishes depending on Indo-West Pacific estuaries or shallow areas include species of Gerreidae and Lutjanidae (Thollot 1992, Blaber 1997). In east Australia, Blaber \& Blaber (1980) found that at least 14 species occurred as juveniles in an estuary and adjacent bay with mangroves and seagrass beds, and that the adults occurred in deeper water or in the Pacific Ocean. They suggested, however, that juveniles do not depend on estuaries per se, but on shallow turbid areas. This conclusion is also true for temperate estuaries (Lenanton 1982, Lenanton \& Potter 1987), but contradicts observations from shallow inland bays of Curaçao, where juvenile nursery species are absent from shallow (turbid) bays lacking mangroves and seagrass beds (Nagelkerken et. al. 2001). Birkeland \& Amesbury (1988) studied the influence of neighbouring habitats on fish community structure and concluded that in the Pacific, interactions among habitats are less pronounced than in the Caribbean, and suggested that Caribbean reef-fish communities may recover more quickly from disturbances through colonization from surrounding habitats.

In conclusion, for at least 4 species, fish densities on the coral reef appear to be a function of the presence of nearby bays containing mangroves and seagrass beds which function as nurseries for the juveniles. For an additional 7 species, the data suggest a similar pattern, although the evidence is not yet sufficient to draw the same conclusion. For 5 other species, no effect of absence of these nursery habitats was found for fish densities on the reef. If the former 11 (commercially important) fish species cannot utilise alternative nursery habitats, anthropogenic impacts on mangroves and seagrass beds resulting in the loss of these nursery habitat could have significant negative impacts on reef fish stocks and yields in the Caribbean.

Acknowledgements. We thank S. Kleijnen, T. Klop, R. A. C. J. van den Brand, M. F. de Jong, W. Soppe, M. de Kluijver, R. Gomez, O. Eerland and J. de Goeij for logistic support in the field, and Dr. J. Ogden for exchanging ideas on this project. I.N., M.D. and M.C.R. were funded by the Beijerinck-Poppingfonds, and E.C.M. was funded by the Netherlands Foundation for the Advancement of Tropical Research (WOTRO). This is Centre for Wetland Ecology publication 315.

\section{LITERATURE CITED}

Bak RPM (1975) Ecological aspects of the distribution of reef corals in the Netherlands Antilles. Bijdr Dierkd 45: 181-190

Birkeland C, Amesbury SS (1988) Fish-transect surveys to determine the influence of neighboring habitats on fish community structure in the tropical Pacific. In: Cooperation for environmental protection in the Pacific. UNEP Regional Seas Rep Stud 97:195-202
Blaber SJM (1997) Fish and fisheries of tropical estuaries. Chapman \& Hall, London

Blaber SJM, Blaber TG (1980) Factors affecting the distribution of juvenile estuarine and inshore fish. J Fish Biol 17: 143-162

Blaber SJM, Brewer DT, Salini JP (1989) Species composition and biomasses of fishes in different habitats of a tropical northern Australian estuary: their occurrence in the adjoining sea and estuarine dependence. Estuar Coast Shelf Sci 29:509-531

Buchan K (1998) Saba, Netherlands Antilles. In: Kjerfve B (ed) CARICOMP - Caribbean coral reef, seagrass and mangrove sites. Coastal region and small island papers (Vol 3), UNESCO, Paris, p 187-193, available at www.unesco.org/ csi/pub/papers/papers3.htm

Cocheret de la Morinière E, Pollux BJA, Nagelkerken I, van der Velde G (2002) Post-settlement life cycle migration patterns and habitat preference of coral reef fish that use seagrass and mangrove habitats as nurseries. Estuar Coast Shelf Sci 55:309-321

García JR, Schmitt C, Heberer C, Winter A (1998) La Parguera, Puerto Rico, USA. In: Kjerfve B (ed) CARICOMPCaribbean coral reef, seagrass and mangrove sites. Coastal region and small island papers (3), UNESCO, Paris, p 187-193, available at www.unesco.org/csi/pub/ papers/papers3.htm

Laegdsgaard P, Johnson C (2001) Why do juvenile fish utilise mangrove habitats? J Exp Mar Biol Ecol 257:229-253

Lenanton RCJ (1982) Alternative non-estuarine nursery habitats for some commercially and recreationally important fish species of south-western Australia. Aust J Mar Freshw Res 33:881-900

Lenanton RCJ, Potter IC (1987) Contribution of estuaries to commercial fisheries in temperate western Australia and the concept of estuarine dependence. Estuaries 10:28-35

Miller MW, Gerstner CL (2002) Reefs of an uninhabited Caribbean island: fishes, benthic habitat, and opportunities to discern reef fishery impact. Biol Conserv 106:37-44

Munro JL (1996) The scope of tropical reef fisheries and their management. In: Polunin NVC, Roberts CM (eds) Reef fisheries. Chapman \& Hall, London, p 1-14

Nagelkerken I, van der Velde G (2002) Non-estuarine mangroves harbour higher densities of juvenile fish than adjacent shallow-water and coral reef habitats in Curaçao (Netherlands Antilles). Mar Ecol Prog Ser 245:in press

Nagelkerken I, van der Velde G (in press) Connectivity between coastal habitats of two oceanic Caribbean islands as inferred from ontogenetic shifts by coral reef fishes. Gulf Caribb Res

Nagelkerken I, Dorenbosch M, Verberk WCEP, Cocheret de la Morinière E, van der Velde G (2000a) Importance of shallow-water biotopes of a Caribbean bay for juvenile coral reef fishes: patterns in biotope association, community structure and spatial distribution. Mar Ecol Prog Ser 202:175-192

Nagelkerken I, van der Velde G, Gorissen MW, Meijer GJ, van't Hof T, den Hartog C (2000b) Importance of mangroves, seagrass beds and the shallow coral reef as a nursery for important coral reef fishes, using a visual census technique. Estuar Coast Shelf Sci 51:31-44

Nagelkerken I, Kleijnen S, Klop T, van den Brand RACJ, Cocheret de la Morinière E, van der Velde G (2001) Dependence of Caribbean reef fishes on mangroves and seagrass beds as nursery habitats: a comparison of fish faunas between bays with and without mangroves/seagrass beds. Mar Ecol Prog Ser 214:225-235

Ogden NB, Gladfelter WG, Ogden JC, Gladfelter EH (1985) 
Marine and terrestrial flora and fauna notes on Sombrero Island in the Caribbean. Atoll Res Bull 292:61-74

Parrish JD (1989) Fish communities of interacting shallowwater habitats in tropical oceanic regions. Mar Ecol Prog Ser 58:143-160

Polunin NVC, Roberts CM (1993) Greater biomass and value of target coral-reef fishes in two small Caribbean marine reserves. Mar Ecol Prog Ser 100:167-176

Roberts CM (1996) Settlement and beyond: population regulation and community structure of reef fishes. In: Polunin NVC, Roberts CM (eds) Reef fisheries. Chapman \& Hall, London, p 85-112

Robertson AI, Blaber SJM (1992) Plankton, epibenthos and fish communities. In: Robertson AI, Alongi DM (eds) Tropical mangrove ecosystems. Coast Estuar Stud 41:173-224 Shepherd SA, McComb AJ, Bulthuis DA, Neverauskas V,

Editorial responsibility: Otto Kinne (Editor),

Oldendorf/Luhe, Germany
Steffensen DA, West R (1989) Decline of seagrasses. In: Larkum AWD, McComb AJ, Shepherd SA (eds) Biology of seagrasses. Elsevier, Amsterdam, p 346-393

Shulman MJ (1985) Recruitment of coral reef fishes: effects of distribution of predators and shelter. Ecology 66: 1056-1066

Shulman MJ, Ogden JC (1987) What controls tropical reef fish populations: recruitment or benthic mortality? An example in the Caribbean reef fish Haemulon flavolineatum. Mar Ecol Prog Ser 39:233-242

Spalding MD (1998) Patterns of biodiversity in coral reefs and mangroves: global and local scales. PhD thesis, University of Cambridge

Thollot P (1992) Importance of mangroves for Pacific reef fish species, myth or reality? Proc 7th Int Coral Reef Symp 2: 934-941

Submitted: February 20, 2002; Accepted: August 13, 2002 Proofs received from author(s): November 11, 2002 